\title{
Evaluation of VEGFA gene variants for possible roles in cerebral infarction diseases
}

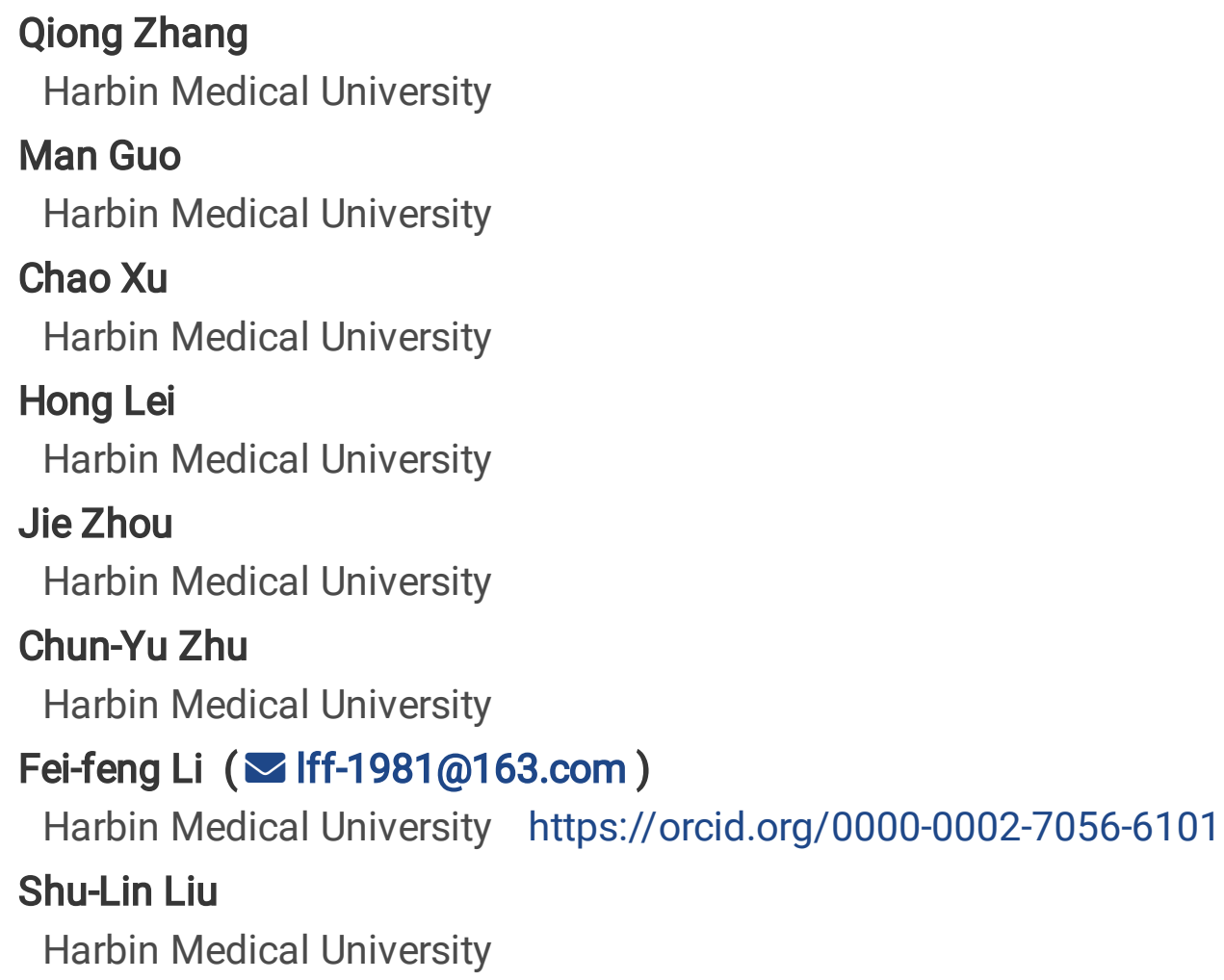

Qiong Zhang

Harbin Medical University

Man Guo

Harbin Medical University

Chao Xu

Harbin Medical University

Hong Lei

Harbin Medical University

Jie Zhou

Harbin Medical University

Chun-Yu Zhu

Harbin Medical University

Fei-feng Li ( $\sim$ lff-1981@163.com )

Harbin Medical University https://orcid.org/0000-0002-7056-6101

Shu-Lin Liu

Harbin Medical University

\section{Research article}

Keywords: Cerebral infarction disease, Cerebral small-vessel disease, Cells proliferation, VEGFA

Posted Date: December 18th, 2019

DOI: https://doi.org/10.21203/rs.2.19207/v1

License: (c) (i) This work is licensed under a Creative Commons Attribution 4.0 International License.

Read Full License 


\section{Abstract}

Background: Cerebral infarction is one of the most common cerebral small vessel diseases. Many angiogenesis relevanted factors have special roles on the diseases pathogenesis. The vascular endothelial growth factor A (VEGFA) is the most prominent stimulating molecule factor for angiogenesis. So, we want to evaluate the correlation between VEGFA gene and this disease in this work.

Methods: The VEGFA gene was sequenced for 400 cerebral infarction patients and 600 normal controls. SPSS software (version 19.0), Plink (version 1.9), Haploview software and online software SNPSpD were used for the statistical analyses and Hardy-Weinberg equilibrium tests.

Results: We found variants rs10434, rs3025040, rs185218985, rs199971699, rs574579489, rs735286 and rs833061 within or near the VEGFA gene. The genetic heterozygosity of rs10434, rs3025040, rs735286 and rs833061 was very high. Statistical analysis showed that the variants rs10434 ( $P=0.041)$ and rs735286 $(P=0.034)$ in the gene were associated with the risk of cerebral infarction diseases in the Chinese Han population.

Conclusions: VEGFA variants rs 10434 and rs735286 were associated with the risk of cerebral infarction diseases in the Chinese Han population.

\section{Introduction}

The Cerebral small vessel diseases (CSVDs) refers to a group of prevalent brain vascular pathological processes, often involved in the cerebral small arteries, venules and capillaries, mainly causing cerebral white and deep grey matter damages ${ }^{[1,2]}$. There are many types of the CSVDs, such as hypertensionrelated cerebral small vessel disease, age-related cerebral small vessel disease and cerebral amyloid angiopathy ${ }^{[3,4]}$. Many brain illnesses including vascular dementia, cognitive impairment, stroke, are often also associated with CSVDs ${ }^{[3-6]}$.

Cerebral infarction is one of CSVDs, often characterized by mental severe hypoxic ischemic tissue necrosis and severe upper extremity impairments ${ }^{[7]}$. Many diseases have been found lead to this disease, such as $20 \%$ of the cerebral infarction cases are cardiogenic cerebral infarction, and about $50 \%$ of the cardiogenic cerebral infarction cases are caused by nonvalvular atrial fibrillation ${ }^{[8,9]}$. In other side, this disease also leading to other diseases, such as sensory disability, language barrier, repeated paralysis, dementia ${ }^{[7,10,11]}$. Although a variety of therapies or methods have been applied to treat the disease in clinical ${ }^{[12,13]}$, but few are effective ${ }^{[14,15]}$.

Disclose the pathogenesis of cerebral infarction diseases (CID), would help exploit new treatment strategies. Patients mental blood vessels blockage is the direct cause of the cerebral infarction diseases, that is resulting from embolism or thrombosis and leading to cerebral ischemia ${ }^{[16]}$. The cerebral ischemia may also induce immune responses and inflammation ${ }^{[17-22]}$. The risk factors documented associated 
with the disease include smoking, obesity, dyslipidemia, high blood pressure ${ }^{[19,23]}$ and cellular apoptosis $[24,25]$.

In the process of vascular cell proliferation, differentiation or apoptosis, many genes involved in, and that also involved in the etiology of the cerebral infarction ${ }^{[19,26,27]}$. The expression of those genes is regulated by the Notch signaling pathway ${ }^{[28-30]}$. This pathway also affects the proliferation of stem/progenitor cells and supports the central and peripheral nervous systems ${ }^{[31]}$. In the previous study, we found that variants in the Notch3 and RBPJ genes are associated with the risk of cerebral infarction diseases ${ }^{[19,32]}$. The Notch3 and RBPJ mediates the process of Notch pathway functioning ${ }^{[3,34]}$. So cellular proliferation, differentiation or apoptosis, and Notch signaling pathway, many have special roles in the pathogenesis of the cerebral infarction diseases.

In the proliferation of many cells, including endothelial cells, neural stem cells and mature astrocytes, the vascular endothelial growth factor $A$ (VEGFA) promotes this process ${ }^{[35]}$. It is also the most prominent stimulating molecule factor for angiogenesis and neurogenesi ${ }^{[36]}$. For example, VEGFA overexpression can improve cognitive performance and neovascularization, hippocampal neurogenesis; blocking the functions of VEGFA, impairs the angiogenesis and neurogenesis and cognitive performance ${ }^{[37]}$. In other side, the VEGFA factor can be produced by many cells, and increasing the vascular permeability of endothelial cells ${ }^{[38,39]}$. However, the correlation between VEGFA and the pathogenesis of cerebral infarction diseases remains unclear.

In this study, we evaluated VEGFA gene variants rs10434, rs3025040, rs735286 and rs833061 for their possible roles in the cerebral infarction disease risk in the Chinese Han population and also demonstrated the relationship between VEGFA factors, vascular cell and cerebral infarction diseases.

\section{Methods}

\section{Study population}

At the Department of Neurology and Medical Examination Center of the Daqing Oilfield General Hospital, Daqing, China, we collected a total of 400 cerebral infarction disease patients and 600 normal controls for this study. We also recorded the clinical features and medical histories of the all the enrolled participants in detail. In the clinical examination, those enrolled participants also carried out the MRI and physical examinations. The detailed clinical features of those enrolled participants were presented in the previous study ${ }^{[19]}$. The experiments were performed in accordance with relevant guidelines and regulations, and we also obtained a written informed consent from each participant. The Ethics Committee of HMU approved this work, which is consistent with the 1975 Declaration of Helsinki.

\section{DNA analysis}


From the peripheral blood of those participants, we extracted the genomic DNA ${ }^{[40,41]}$. Then we were amplified the splicing sites and transcribed regions of VEGFA gene using the primers shown in Table 1 , and as previously shown for mutational analysis we were sequenced the PCR products ${ }^{[42]}$.

Table 1

PCR primers used for VEGFA gene sequence analysis

\begin{tabular}{|lllll|}
\hline Exon & Forward primer & Reverse primer & Size & Tm \\
\hline $1 \mathrm{a}$ & GCGAGCAGCGAAAGCGACAG & GCAGCAAGGCAAGGCTCCAAT & 694 & 64.1 \\
\hline b & GGCTCATGGACGGGTGAGG & ACTCCGGTGGGTGGGCAG & 493 & 63.0 \\
\hline 2 & AGGGAAGTGAGGAGGGAG & TCACGAAACTGAGGGTGAA & 312 & 55.4 \\
\hline 3 & TTACAGAGCTGGGTGGAGA & GAGCCAGACAAGGCAAAT & 383 & 54.9 \\
\hline 4 & GTATGGCTGGCTGGGTCA & GCCAAAGGTCACATAGCG & 248 & 53.1 \\
\hline 5 & CACCATCTTAACCCTTCC & ACTAGCCCTAGAGCCATC & 269 & 52.5 \\
\hline 6 & GCTTTGCTTTGGTCGTTC & GGTGCCAATTAGTGGAGTG & 340 & 54.8 \\
\hline 7 & GGGTGTTGCATGGTGATT & CAGGCAGGCAGCTAGAAA & 354 & 53.8 \\
\hline $8 \mathrm{a}$ & TGGGGCTGTTCTCATACT & CTCTTCCCTGTCAGGATC & 742 & 52.0 \\
\hline $8 \mathrm{~b}$ & TATTGGTGTCTTCACTGGA & CAGGGGATGGAGGAAGGT & 679 & 54.1 \\
\hline
\end{tabular}

\section{SNP genotyping analysis}

We determined the variations of the VEGFA gene in the enrolled cerebral infarction patients and controls, and the measurements were conducted by two researchers independently. Finally overall the genetics correlation analysis was conducted.

\section{Statistical analysis}

We were conducted the statistical analyses and Hardy-Weinberg equilibrium tests of the study participants using SPSS software (version 19.0) ${ }^{[43]}$ and Plink (version 1.9) ${ }^{[44,45]}$. And as previously study showen, using the online software SNPSpD and Haploview software, we were calculated the experimentwide significance threshold and the matrix of mpirwise linkage-disequilibrium (LD) correlation ${ }^{[46]}$.

\section{Results}


In this work, we sequenced the VEGFA gene, in order to evaluate variations in VEGFA gene for their possible associations with the cerebral infarction diseases susceptibility. We were characterized the variants rs10434, rs3025040, rs185218985, rs199971699, rs574579489, rs735286 and rs833061 within or near the VEGFA gene (Fig. 1A). Farther analysis showed that the genetic heterozygosity of rs 10434 , rs3025040, rs735286 and rs833061 was very high, whereas that of rs185218985, rs199971699 and rs574579489 was very low and were excluded from further analysis (Table 2).

Table 2

The genotype and allele frequency of rs10434, rs3025040, rs735286 and rs833061 varients in 400 Chinese Han cerebral infarction and 600 normal agedness controls.

\begin{tabular}{|c|c|c|c|c|c|c|c|}
\hline \multirow{2}{*}{$\begin{array}{l}\text { Variations } \\
\text { rs10434 }\end{array}$} & \multirow{2}{*}{\multicolumn{2}{|c|}{$\begin{array}{l}\text { Group } \\
\text { Genotype }\end{array}$}} & \multicolumn{3}{|c|}{ Genotype frequency (\%) } & \multicolumn{2}{|c|}{ Allele frequency (\%) } \\
\hline & & & $\mathrm{G} / \mathrm{G}$ & $\mathrm{G} / \mathrm{A}$ & $A / A$ & G & $A$ \\
\hline & CID & 400 & $256(64.0 \%)$ & $138(34.5 \%)$ & $6(1.5 \%)$ & $650(81.3 \%)$ & $150(18.8 \%)$ \\
\hline & Control & 600 & $394(65.7 \%)$ & $182(30.3 \%)$ & $24(4.0 \%)$ & $970(80.8 \%)$ & $230(19.2 \%)$ \\
\hline \multirow[t]{3}{*}{ rs3025040 } & \multicolumn{2}{|c|}{ Genotype } & $\mathrm{C} / \mathrm{C}$ & $\mathrm{C} / \mathrm{T}$ & $\mathrm{T} / \mathrm{T}$ & C & $\mathrm{T}$ \\
\hline & CID & 400 & $246(61.5 \%)$ & $143(35.8 \%)$ & $11(2.8 \%)$ & $635(79.4 \%)$ & $165(20.6 \%)$ \\
\hline & Control & 600 & $394(65.7 \%)$ & $188(31.3 \%)$ & $18(3.0 \%)$ & $976(81.3 \%)$ & $224(18.7 \%)$ \\
\hline \multirow[t]{3}{*}{ rs735286 } & \multicolumn{2}{|l|}{ Genotype } & $\mathrm{G} / \mathrm{G}$ & $G / A$ & $A / A$ & G & $A$ \\
\hline & CID & 400 & $127(31.8 \%)$ & $212(53.0 \%)$ & $61(15.3 \%)$ & $466(58.3 \%)$ & $334(41.8 \%)$ \\
\hline & Control & 600 & $239(39.8 \%)$ & $281(46.8 \%)$ & $80(13.3 \%)$ & $759(63.3 \%)$ & $441(36.8 \%)$ \\
\hline \multirow[t]{3}{*}{ rs833061 } & \multicolumn{2}{|c|}{ Genotype } & $T / T$ & $\mathrm{~T} / \mathrm{C}$ & $\mathrm{C} / \mathrm{C}$ & $\mathrm{T}$ & C \\
\hline & CID & 400 & $187(46.8 \%)$ & $175(43.8 \%)$ & $38(9.5 \%)$ & $549(68.6 \%)$ & $251(31.4 \%)$ \\
\hline & Control & 600 & $250(41.7 \%)$ & $283(47.2 \%)$ & $67(11.2 \%)$ & $783(65.3 \%)$ & $417(34.8 \%)$ \\
\hline
\end{tabular}

\section{Polymorphism-disease association analyses}

In order to, evalute their possible associations with the cerebral infarction disease, we conducted analyses on those SNPs and found rs10434 ( $P=0.041)$ and rs735286 ( $P=0.034)$ within VEGFA gene were associated with the risk of this disease in Chinese Han population (Tables 2, 3). At the sime time, we also conducted the Hardy-Weinberg equilibrium test for the cerebral infarction disease and control populations, and found they were in line with equilibrium (Tables 4). 
Table 3

Varients rs 10434 and rs735286 within the VEGFA gene were associated with risk of cerebral infarction in Chinese Han populations

\begin{tabular}{|c|c|c|c|c|c|c|c|c|}
\hline \multicolumn{2}{|l|}{ Title } & \multicolumn{4}{|c|}{ Pearson Chi-square } & \multicolumn{3}{|l|}{ Risk } \\
\hline $\begin{array}{l}\text { Genotyped } \\
\text { SNP }\end{array}$ & $\begin{array}{l}\text { Statistical } \\
\text { Types }\end{array}$ & Value & $\begin{array}{l}\text { Min } \\
\text { count }^{a}\end{array}$ & df & $\begin{array}{l}\text { Asymp. Sig. (2- } \\
\text { sided) }\end{array}$ & Value & $\begin{array}{l}95 \% \mathrm{Cl}- \\
\text { low }\end{array}$ & $\begin{array}{l}95 \% \mathrm{Cl}- \\
\text { up }\end{array}$ \\
\hline \multirow[t]{2}{*}{ rs10434 } & Genotype & 6.405 & 12.0 & 2 & $0.041^{*}$ & - & - & - \\
\hline & Allele & 0.054 & 152.0 & 1 & 0.816 & 1.027 & 0.818 & 1.291 \\
\hline \multirow[t]{2}{*}{ rs3025040 } & Genotype & 2.117 & 11.6 & 2 & 0.347 & - & - & - \\
\hline & Allele & 1.175 & 155.6 & 1 & 0.278 & 0.883 & 0.706 & 1.106 \\
\hline \multirow[t]{2}{*}{ rs735286 } & Genotype & 6.761 & 56.4 & 2 & $0.034^{*}$ & - & - & - \\
\hline & Allele & 5.056 & 310.0 & 1 & $0.025^{\star}$ & 0.811 & 0.675 & 0.974 \\
\hline \multirow[t]{2}{*}{ rs833061 } & Genotype & 2.666 & 42.0 & 2 & 0.264 & - & - & - \\
\hline & Allele & 2.458 & 267.2 & 1 & 0.117 & 1.165 & 0.962 & 1.410 \\
\hline
\end{tabular}

Table 4

Hardy-Weinberg equilibrium test for the study population groups

\begin{tabular}{|lllll|}
\hline \multirow{2}{*}{ SNPs } & Genotype & \multicolumn{3}{c|}{ H-W equilibrium Testing } \\
\cline { 2 - 5 } & Homo/Hetero/Homozygote & O(HET) & E (HET) & P \\
\hline rs10434 & $30 / 320 / 650$ & 0.320 & 0.3078 & 0.2577 \\
\hline rs3025040 & $29 / 331 / 640$ & 0.331 & 0.3133 & 0.0858 \\
\hline rs735286 & $141 / 493 / 366$ & 0.493 & 0.4747 & 0.2312 \\
\hline rs833061 & $105 / 458 / 437$ & 0.458 & 0.4449 & 0.3936 \\
\hline
\end{tabular}

The experiment-wide significance threshold required to keep Type I error rate at $5 \%$ of rs 10434 , rs 3025040 , rs 735286 and rs 833061 within the VEGFA gene was 0.018 . The variants rs 10434 , rs 3025040 , rs 735286 and rs833061 LD analysis was conducted using the Haploview software, and it was consistent with the HapMap CHB population data (Fig. 2). The genotype frequencies of cerebral infarction disease and control groups were also analyzed by trend, dominant and recessive models, and all those results indicated rs10434 and rs735286 were associated with the risk of cerebral infarction diseases (Table 5). 
Table 5

SNP rs10434 and rs735286 within VEGFA gene associated with the risk of cerebral infarction diseases

\begin{tabular}{|lllll|}
\hline SNPs & Value & Trend model & Dominant model & Recessive model \\
\hline rs10434 & ChisQ & 0.0564 & 0.2930 & 5.1550 \\
\cline { 2 - 5 } & P & 0.8123 & 0.5883 & $0.0232^{\star}$ \\
\hline rs735286 & ChisQ & 5.2590 & 6.7580 & 0.7279 \\
\cline { 2 - 5 } & P & $0.0218^{*}$ & $0.0093^{*}$ & 0.3936 \\
\hline \multirow{2}{*}{ *: statistically significant } & & \\
\hline
\end{tabular}

\section{Discussion}

Cerebral blood vessels systems characteristics changes is the main cause of cerebral infarction diseases, and many physiologic or pathologic conditions have been found contribute to vascular characteristics changes or cerebral infarction ${ }^{[16,47]}$. The VEGFA factor can strengthen neoangiogenesis under those conditions and maintain the blood vessels homeostasis ${ }^{[48]}$, VEGFA may also mediate the response of increases in permeability and angiogenesis, especially in brain ${ }^{[49]}$. In the endothelial cells, VEGFA can facilitating cellular migration and sprouting ${ }^{[50]}$, and also have some roles in cancer pathology, inflammation and wound healing ${ }^{[51,52]}$.

It is important to explore the pathogenesis of VEGFA in those diseases, such as cerebral infarction diseases. It has been found that VEGFA factors can disrupt vascular pericytes coverage and stop the newborn vessels maturation ${ }^{[53]}$. However, after cerebral ischemia, VEGFA factors can also induce the proliferation of endothelial cells in angiogenesis, and after subarachnoid hemorrhage, the factors can promote the formation of brain edema ${ }^{[53,54]}$. The expression level of VEGFA factors may also increase the increase the risk of cerebral infarction disease ${ }^{[54]}$ and plaque rupture ${ }^{[55]}$. Because in the brain infarct area, the new small blood vessels can improve blood supply, but also cause bleeding due to the vascular rupture $^{[56]}$. So the relationship between the VEGFA factors, vascular development and cerebral infarction diseases was very complex, it is may depend on the VEGFA factors released place, time and level. The results of this work, further confirmed the special roles of VEGFA in pathogenesis of cerebral infarction diseases.

In the development of the vessel, vascular cell proliferation, differentiation and apoptosis take it, and those cellular life process are regulated by Notch signaling pathway ${ }^{[28]}$. Many variations in the genes that interact with the pathway could result in severe defects in the angiogenic vascular remodeling and lead to embryonic lethality ${ }^{[57,58]}$. Our previous works have showed the importance of Notch signaling pathway factors Notch3 and RBPJ in the pathogenesis of the cerebral infarction diseases ${ }^{[19,32]}$. It is interesting that 
the VEGFA factor also promotes the proliferation of endothelial cells, neural stem cells and mature astrocytes $^{[35]}$, and also stimulates molecule factor for angiogenesis and neurogenesis ${ }^{[36]}$. Those results further proved the important roles of normal vascular cell life process in the pathogenesis of the cerebral infarction diseases.

In this study, we identified genetic variations rs10434 and rs735286 in the VEGFA gene were related with the risk of cerebral infarction diseases. Variation rs735286 was located within the third intron. It has been found that some untranslated regions of the gene includes key regulatory elements that is responsive to hypoxia ${ }^{[59]}$. VEGFA gene variation $+936 \mathrm{C} / \mathrm{T}$ resides in the 3-untranslated region, is associated with the risk of stroke ${ }^{[60]}$ and VEGFA serum levels ${ }^{[61]}$. Variation $-2578 \mathrm{C} / \mathrm{A}$ located at the VEGFA gene promoter region is correlated with a decreased VEGF expression ${ }^{[62]}$ and the risk of stroke ${ }^{[60]}$. We found the site of variation rs 10434 was within the $3^{\prime} \mathrm{UTR}$ of the gene, and it is associated with the risk of cerebral infarction diseases. However the specific functions of rs10434 in the 3'UTR region or the gene, is not completely clear. Combined the fact that VEGFA factor mediates angiogenesis was very complex, more works on the functions of special region of VEGFA may be needed.

\section{Conclusion}

We evaluated the risk between rs10434 and rs735286 inVEGFR gene and cerebral infarction diseases in Chinese Han population and demonstrated the relationship between VEGFA factors, vascular cell and cerebral infarction diseases.

\section{Declarations}

Ethics approval and consent to participate: Ethics Committee of Harbin Medical University. The experiments were performed in accordance with relevant guidelines and regulations, and all participants in this study signed a written informed consent.

Consent to publish: Not applicable.

Availability of data and materials: Not applicable.

Competing interests: The authors have declared that no competing interests exist.

Funding: This work was supported by grants of National Natural Science Foundation of China (NSFC30870098, 30970119, 81030029, 81271786, 81671980, 31671283); University Student Innovation Foundation of Heilongjiang (201910226035).

Authors' Contributions : Study concept or design: FFL, SLL; specimen collection: QZ, HL, JZ, CYZ; experiment: QZ, MG, CX, HL, JZ, CYZ; funding: FFL, SLL; drafting/revising of manuscript: all the authors.

Acknowledgements: The authors thank the patients and their families for their cooperation and participation in this study. 


\section{References}

1. Teng Z, Dong Y, Zhang D, An J, Lv P: Cerebral small vessel disease and post-stroke cognitive impairment. Int J Neurosci 2016:1-7.

2. Tan R, Traylor M, Rutten-Jacobs $L$, Markus $H$ : New insights into mechanisms of small vessel disease stroke from genetics. Clin Sci (Lond) 2017, 131(7):515-531.

3. Charidimou A, Pantoni L, Love S: The concept of sporadic cerebral small vessel disease: A road map on key definitions and current concepts. Int J Stroke 2016, 11(1):6-18.

4. Norrving B: Evolving Concept of Small Vessel Disease through Advanced Brain Imaging. J Stroke 2015, 17(2):94-100.

5. Pantoni L: Cerebral small vessel disease: from pathogenesis and clinical characteristics to therapeutic challenges. Lancet Neurol 2010, 9(7):689-701.

6. Rutten-Jacobs LC, Traylor M, Adib-Samii P, Thijs V, Sudlow C, Rothwell PM, Boncoraglio G, Dichgans M, Bevan S, Meschia J et al: Common NOTCH3 Variants and Cerebral Small-Vessel Disease. Stroke 2015, 46(6):1482-1487.

7. Thajeb P: Gait disorders of multi-infarct dementia. CT and clinical correlation. Acta Neurol Scand 1993, 87(3):239-242.

8. Kernan WN, Ovbiagele B, Black HR, Bravata DM, Chimowitz MI, Ezekowitz MD, Fang MC, Fisher M, Furie KL, Heck DV et al: Guidelines for the prevention of stroke in patients with stroke and transient ischemic attack: a guideline for healthcare professionals from the American Heart Association/American Stroke Association. Stroke 2014, 45(7):2160-2236.

9. Sun W, Li G, Zeng X, Lai Z, Wang M, Ouyang Y, Zeng G, Peng J, Zhong J, Xiao D et al: Clinical and Imaging Characteristics of Cerebral Infarction in Patients with Nonvalvular Atrial Fibrillation Combined with Cerebral Artery Stenosis. J Atheroscler Thromb 2018, 25(8):720-732.

10. Liu Y, Zhang Y, Lin L, Lin F, Li T, Du H, Chen R, Zheng W, Liu N: Effects of bone marrow-derived mesenchymal stem cells on the axonal outgrowth through activation of PI3K/AKT signaling in primary cortical neurons followed oxygen-glucose deprivation injury. PLOS One 2013, 8(11):e78514.

11. Nowak DA: The impact of stroke on the performance of grasping: usefulness of kinetic and kinematic motion analysis. Neurosci Biobehav Rev 2008, 32(8):1439-1450.

12. Fugate JE, Rabinstein AA: Absolute and Relative Contraindications to IV rt-PA for Acute Ischemic Stroke. Neurohospitalist 2015, 5(3):110-121.

13. Jeong HS, Song HJ, Kim SB, Lee J, Kang CW, Koh HS, Shin JE, Lee SH, Kwon HJ, Kim J: A comparison of stent-assisted mechanical thrombectomy and conventional intra-arterial thrombolysis for acute cerebral infarction. J Clin Neurol 2013, 9(2):91-96.

14. Liu N, Zhang Y, Fan L, Yuan M, Du H, Cheng R, Liu D, Lin F: Effects of transplantation with bone marrow-derived mesenchymal stem cells modified by Survivin on experimental stroke in rats. $J$ Transl Med 2011, 9:105. 
15. Han KT, Park EC, Kim SJ, Kim W, Hahm MI, Jang SI, Lee SG: Effective strategy for improving health care outcomes: Multidisciplinary care in cerebral infarction patients. Health Policy 2015, 119(8):10391045.

16. Wang S, Zhou J, Kang W, Dong Z, Wang H: Tocilizumab inhibits neuronal cell apoptosis and activates STAT3 in cerebral infarction rat model. Bosn J Basic Med Sci 2016.

17. Wang H, Guo W, Liu H, Zeng R, Lu M, Chen Z, Xiao Q: Inhibition of inflammatory mediator release from microglia can treat ischemic/hypoxic brain injury. Neural Regen Res 2013, 8(13):1157-1168.

18. Tu Q, Cao H, Zhong W, Ding B, Tang X: Atorvastatin protects against cerebral ischemia/reperfusion injury through anti-inflammatory and antioxidant effects. Neural Regen Res 2014, 9(3):268-275.

19. Zhu CY, Wang Y, Zeng QX, Qian Y, Li H, Yang ZX, Yang YM, Zhang Q, Li FF, Liu SL: Combined effects of age and polymorphisms in Notch3 in the pathogenesis of cerebral infarction disease. Metab Brain Dis 2016, 31(5):1157-1164.

20. Zhang HR, Peng JH, Zhu GY, Xu RX: Neuroprotective effects of Bcl-2 overexpression on nerve cells of rats with acute cerebral infarction. Genet Mol Res 2015, 14(3):7696-7703.

21. Zhao JH, Xu YM, Xing HX, Su LL, Tao SB, Tian XJ, Yan HQ, Ji SB: Associations between matrix metalloproteinase gene polymorphisms and the development of cerebral infarction. Genet Mol Res 2016, 14(4):19418-19424.

22. Yellon DM, Hausenloy DJ: Myocardial reperfusion injury. N Engl J Med 2007, 357(11):1121-1135.

23. Gjerde G, Naess H: Risk factor burden predicts long-term mortality after cerebral infarction. Acta Neurol Scand 2014, 129(3):173-177.

24. Ling L, Zeng J, Pei Z, Cheung RT, Hou Q, Xing S, Zhang S: Neurogenesis and angiogenesis within the ipsilateral thalamus with secondary damage after focal cortical infarction in hypertensive rats. $J$ Cereb Blood Flow Metab 2009, 29(9):1538-1546.

25. Liao SJ, Gong Q, Chen XR, Ye LX, Ding Q, Zeng JS, Yu J: Netrin-1 rescues neuron loss by attenuating secondary apoptosis in ipsilateral thalamic nucleus following focal cerebral infarction in hypertensive rats. Neuroscience 2013, 231:225-232.

26. Guan J, Wei X, Qu S, Lv T, Fu Q, Yuan Y: Osthole prevents cerebral ischemia/reperfusion injury via Notch signaling pathway. Biochem Cell Biol 2017.

27. Yuan Y, Rangarajan P, Kan EM, Wu Y, Wu C, Ling EA: Scutellarin regulates the Notch pathway and affects the migration and morphological transformation of activated microglia in experimentally induced cerebral ischemia in rats and in activated BV-2 microglia. J Neuroinflammation 2015, 12:11.

28. Maillard I, Fang T, Pear WS: Regulation of lymphoid development, differentiation, and function by the Notch pathway. Annu Rev Immunol 2005, 23:945-974.

29. Li L, Xie T: Stem cell niche: structure and function. Annu Rev Cell Dev Biol2005, 21:605-631.

30. Penton AL, Leonard LD, Spinner NB: Notch signaling in human development and disease. Semin Cell Dev Biol 2012, 23(4):450-457. 
31. Shen Z, Hou X, Chen B, Chen P, Zhang Q: NOTCH3 gene polymorphism is associated with the prognosis of gliomas in Chinese patients. Medicine (Baltimore) 2015, 94(9):e482.

32. Zhang Q, Zhou J, Lei H, Zhu CY, Li FF, Zheng D, Liu SL: RBPJ polymorphisms associated with cerebral infarction diseases in Chinese Han population: A Clinical Trial/Experimental Study (CONSORT Compliant). Medicine (Baltimore) 2018, 97(31):e11420.

33. Castel D, Mourikis P, Bartels SJ, Brinkman AB, Tajbakhsh S, Stunnenberg HG: Dynamic binding of RBPJ is determined by Notch signaling status. Genes Dev 2013, 27(9):1059-1071.

34. Hori K, Cholewa-Waclaw J, Nakada Y, Glasgow SM, Masui T, Henke RM, Wildner H, Martarelli B, Beres TM, Epstein JA et al: A nonclassical bHLH Rbpj transcription factor complex is required for specification of GABAergic neurons independent of Notch signaling. Genes Dev 2008, 22(2):166-178.

35. Jin K, Zhu Y, Sun Y, Mao XO, Xie L, Greenberg DA: Vascular endothelial growth factor (VEGF) stimulates neurogenesis in vitro and in vivo. Proc Natl Acad Sci U S A 2002, 99(18):11946-11950.

36. Fabel K, Tam B, Kaufer D, Baiker A, Simmons N, Kuo CJ, Palmer TD: VEGF is necessary for exerciseinduced adult hippocampal neurogenesis. Eur J Neurosci 2003, 18(10):2803-2812.

37. Kiuchi T, Lee H, Mikami T: Regular exercise cures depression-like behavior via VEGF-Flk-1 signaling in chronically stressed mice. Neuroscience 2012, 207:208-217.

38. Chen X, Zheng Z, Chen L, Zheng H: MAPK, NFkappaB, and VEGF signaling pathways regulate breast cancer liver metastasis. Oncotarget 2017, 8(60):101452-101460.

39. Schirosi L, De Summa S, Tommasi S, Paradiso A, Gasparini G, Popescu O, Simone G, Mangia A: VEGF and TWIST1 in a 16-biomarker immunoprofile useful for prognosis of breast cancer patients. Int $J$ Cancer 2017, 141(9):1901-1911.

40. Li FF, Liu Z, Yan P, Shao X, Deng X, Sam C, Chen YG, Xu YP, Wang XS, Wang GY et al: Identification of a novel mutation associated with familial adenomatous polyposis and colorectal cancer. Int $\mathrm{J} \mathrm{Mol}$ Med 2015, 36(4):1049-1056.

41. Tan ZX, Li FF, Qu YY, Liu J, Liu GR, Zhou J, Zhu YL, Liu SL: Identification of a known mutation in Notch 3 in familiar CADASIL in China. PLoS One 2012, 7(5):e36590.

42. Li FF, Han Y, Shi S, Li X, Zhu XD, Zhou J, Shao QL, Li XQ, Liu SL: Characterization of Transcriptional Repressor Gene MSX1 Variations for Possible Associations with Congenital Heart Diseases. PLOS One 2015, 10(11):e0142666.

43. Deng X, Zhou J, Li FF, Yan P, Zhao EY, Hao L, Yu KJ, Liu SL: Characterization of nodal/TGF-lefty signaling pathway gene variants for possible roles in congenital heart diseases. PLoS One 2014, 9(8):e104535.

44. Li FF, Zhou J, Zhao DD, Yan P, Li X, Han Y, Li XS, Wang GY, Yu KJ, Liu SL: Characterization of SMAD3 Gene Variants for Possible Roles in Ventricular Septal Defects and Other Congenital Heart Diseases. PLoS One 2015, 10(6):e0131542.

45. Li X, Shi S, Li FF, Cheng R, Han Y, Diao LW, Zhang Q, Zhi JX, Liu SL: Characterization of soluble Nethylmaleimide-sensitive factor attachment protein receptor gene STX18 variations for possible roles in congenital heart diseases. Gene 2017, 598:79-83. 
46. Li FF, Zhu XD, Yan P, Jin MH, Yue H, Zhang Q, Fu J, Liu SL: Characterization of variations in IL23A and IL23R genes: possible roles in multiple sclerosis and other neuroinflammatory demyelinating diseases. Aging (Albany NY) 2016, 8(11):2734-2746.

47. Zhang C, Feng F, Zhu Y, Wang R, Xing B: Cerebral infarction caused by pituitary apoplexy: case report and review of literature. Turk Neurosurg 2014, 24(5):782-787.

48. Lee S, Chen TT, Barber CL, Jordan MC, Murdock J, Desai S, Ferrara N, Nagy A, Roos KP, Iruela-Arispe ML: Autocrine VEGF signaling is required for vascular homeostasis. Cel/2007, 130(4):691-703.

49. Ogunshola OO, Stewart WB, Mihalcik V, Solli T, Madri JA, Ment LR: Neuronal VEGF expression correlates with angiogenesis in postnatal developing rat brain. Brain Res Dev Brain Res 2000, 119(1):139-153.

50. Unemori EN, Ferrara N, Bauer EA, Amento EP: Vascular endothelial growth factor induces interstitial collagenase expression in human endothelial cells. J Cell Physiol 1992, 153(3):557-562.

51. Li X, Lu Y, Wei P: Association between VEGF genetic variants and diabetic foot ulcer in Chinese Han population: A case-control study. Medicine (Baltimore) 2018, 97(20):e10672.

52. He QS, Yang LF, Wang WB, Yuan B, Zhang LY, Guo XJ: Vascular endothelial growth factor gene is associated with hypertensive cerebellar hemorrhage and rehabilitative treatment. Genet Mol Res 2015, 14(3):9849-9857.

53. Hermann DM, Zechariah A: Implications of vascular endothelial growth factor for postischemic neurovascular remodeling. J Cereb Blood Flow Metab 2009, 29(10):1620-1643.

54. Liu L, Fujimoto M, Kawakita F, Ichikawa N, Suzuki H: Vascular Endothelial Growth Factor in Brain Edema Formation After Subarachnoid Hemorrhage. Acta Neurochir Supp/2016, 121:173-177.

55. Camare C, Pucelle M, Negre-Salvayre A, Salvayre R: Angiogenesis in the atherosclerotic plaque. Redox Biol 2017, 12:18-34.

56. Lee CZ, Xue Z, Zhu Y, Yang GY, Young WL: Matrix metalloproteinase-9 inhibition attenuates vascular endothelial growth factor-induced intracerebral hemorrhage. Stroke 2007, 38(9):2563-2568.

57. Fischer A, Schumacher N, Maier M, Sendtner M, Gessler M: The Notch target genes Hey1 and Hey2 are required for embryonic vascular development. Genes Dev 2004, 18(8):901-911.

58. Krebs LT, Xue Y, Norton CR, Shutter JR, Maguire M, Sundberg JP, Gallahan D, Closson V, Kitajewski J, Callahan $\mathrm{R}$ et al: Notch signaling is essential for vascular morphogenesis in mice. Genes Dev 2000, 14(11):1343-1352.

59. Liu Y, Cox SR, Morita T, Kourembanas S: Hypoxia regulates vascular endothelial growth factor gene expression in endothelial cells. Identification of a 5' enhancer. Circ Res 1995, 77(3):638-643.

60. Xu B, Zhan R, Mai H, Wu Z, Zhu P, Liang Y, Zhang Y: The association between vascular endothelial growth factor gene polymorphisms and stroke: A PRISMA-compliant meta-analysis. Medicine (Baltimore) 2019, 98(11):e14696.

61. Egger M, Davey Smith G, Schneider M, Minder C: Bias in meta-analysis detected by a simple, graphical test. BMJ 1997, 315(7109):629-634. 
62. Mohammadi M, Bazrafshani MR, Day PJ, Ollier WE: Vascular endothelial growth factor production is regulated by gene polymorphisms. Iran J Immunol 2009, 6(3):119-129.

\section{Figures}

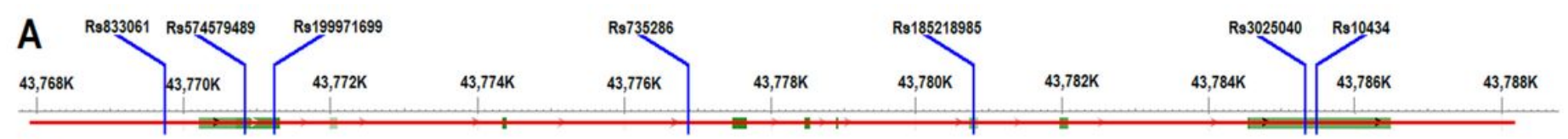

\section{B}

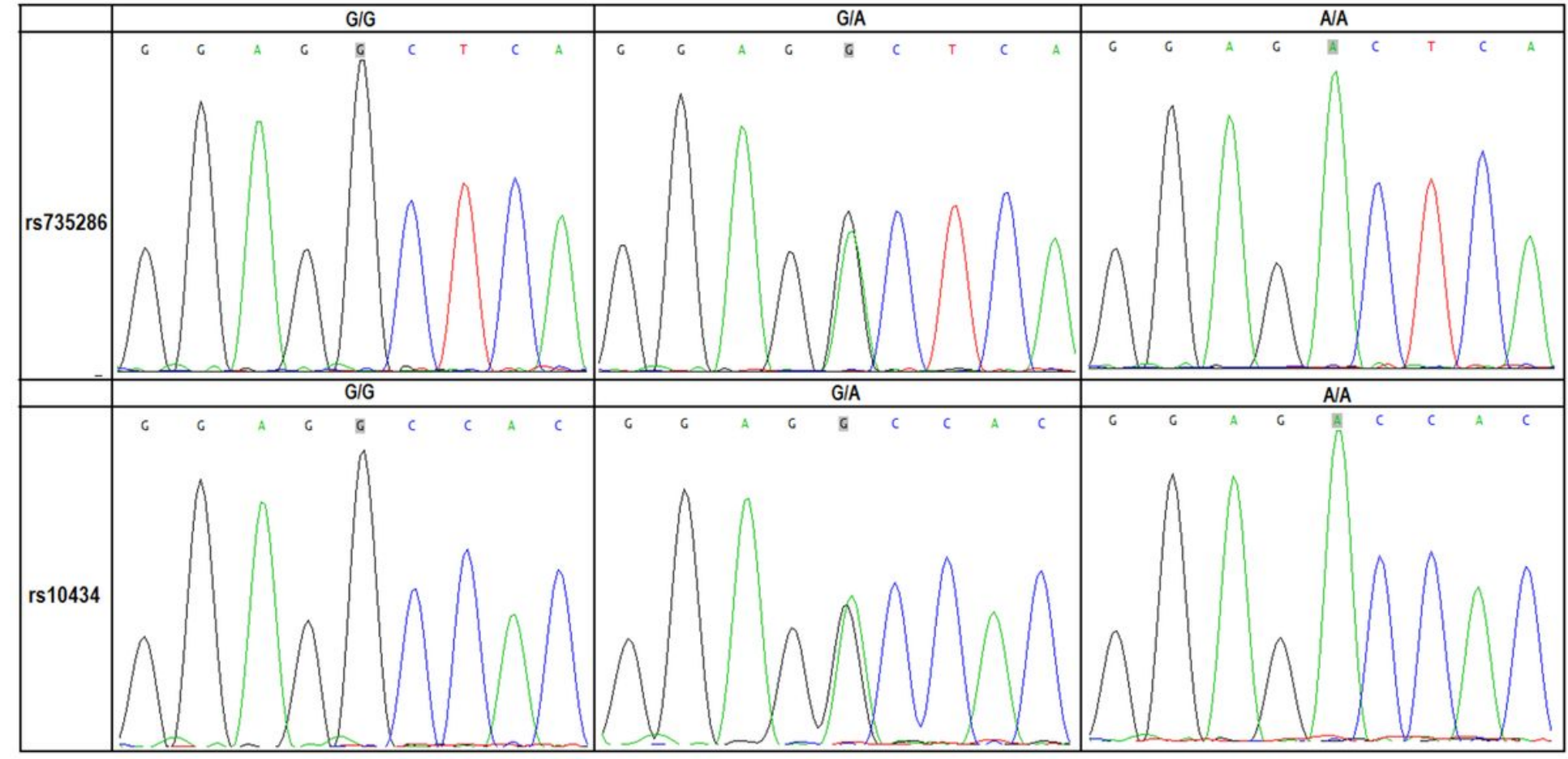

\section{Figure 1}

Schematic diagrams and DNA sequence chromatograms. A: Schematic diagrams of rs 10434, rs 3025040 , rs 185218985, rs199971699, rs574579489, rs735286 and rs833061 within or near the VEGFA gene; B: Three genotypes of DNA sequence chromatograms of rs735286 and rs10434. 


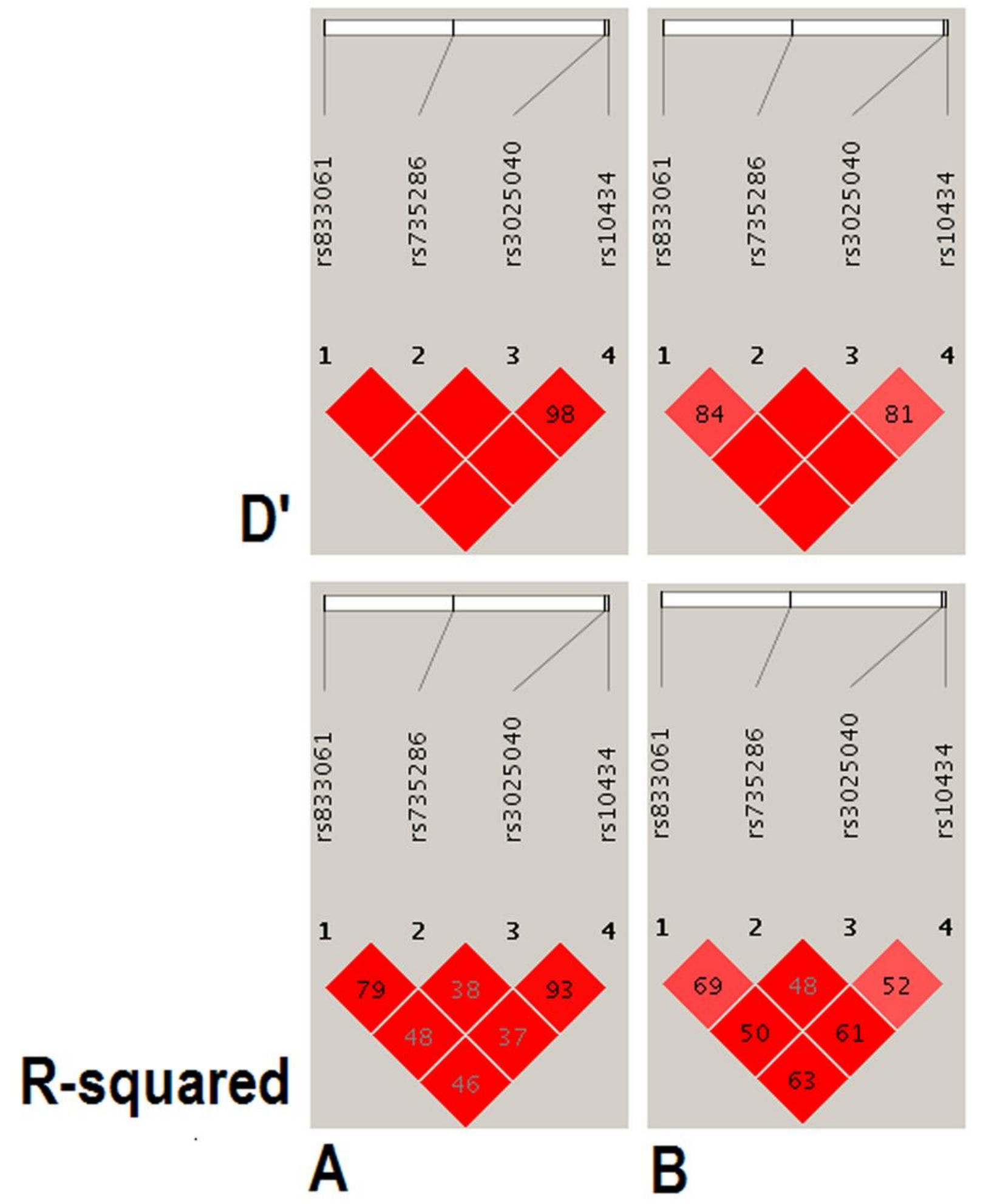

\section{Figure 2}

LD analysis for rs10434, rs3025040, rs735286 and rs833061 within VEGFA gene. A: Data analysis between the cerebral infarction diseases patients and controls in present study; B: Data from HapMap $\mathrm{CHB}$. The data of this work and from HapMap CHB were consistent. 